\title{
PEMODELAN DEFORESTASI HUTAN LINDUNG DI INDONESIA MENGGUNAKAN MODEL GEOGRAPHICALLY AND TEMPORALLY WEIGHTED REGRESSION (GTWR)
}

\author{
Thea Zulfa Adiningrum ${ }^{1}$, Alan Prahutama ${ }^{2}$, Rukun Santoso. ${ }^{3}$ \\ 1,2,3 Departemen Statistika, Fakultas Sains dan Matematika, Universitas Diponegoro \\ e-mail : thea.zulfa@gmail.com
}

\begin{abstract}
Regression analysis is a statistical analysis method that is used to modeling the relationship between dependent variables and independent variables. In the linear regression model only produced parameter estimators are globally, so it's often called global regression. While to analyze spatial data can be used Geographically Weighted Regression (GWR) method. Geographically and Temporally Weighted Regression (GTWR) is the development of GWR model to handle the instability of a data both from the spatial and temporal sides simultaneously. In this GWR modeling the weight function used is a Gaussian Kernel, which requires the bandwidth value as a distance parameter. Optimum bandwidth can be obtained by minimizing the CV (cross validation) coefficient value. By comparing the R-square, Mean Square Error (MSE) and Akaike Information Criterion (AIC) values in both methods, it is known that modeling the level of deforestation in protected forest areas in Indonesia in 2013 through 2016 uses the GTWR method better than global regression. With the Rsquare value the GTWR model is $25.1 \%$, the MSE value is 0.7833 and AIC value is 349,6917 . While the global regression model has R-square value of $15.8 \%$, MSE value of 0.861 and AIC value of 361,3328.
\end{abstract}

Keywords : GWR, GTWR, Bandwidth, Kernel Gaussian

\section{PENDAHULUAN}

Hutan merupakan elemen penting yang harus dijaga kelestariannya dikarenakan banyak manfaat yang diberikan oleh hutan untuk keberlangsungan hidup manusia. Indonesia memiliki hutan tropis ketiga terluas di dunia setelah Brazil dan Zaire, sehingga hutan Indonesia sangat penting peranannya sebagai bagian dari paru-paru dunia serta penyeimbang iklim global. Penutupan lahan pada kawasan hutan memiliki sifat yang sangat dinamis. Perubahan yang terjadi dengan cepat meyebabkan kondisi hutan semakin menurun dan berkurang luasnya. Berkurangnya luasan pada hutan juga sering disebabkan oleh adanya deforestasi pada hutan atau yang sering kita sebut sebagai penggundulan hutan. Deforestasi sendiri memiliki artian yang lebih dalam sebagai hilangnya atau terdegradasinya habitat hutan yang disebabkan oleh alam atau ulah manusia (Nawir, 2008). Menurut Revilla (1993) dalam Mutiara et al. (2018a), Indonesia kehilangan penutupan hutan selama tahun 19721990 seluas $840.000 \mathrm{ha} /$ tahun atau seluas $0,68 \%$ per tahun.

Tingkat deforestasi hutan-hutan di Indonesia memiliki perbedaan pada setiap daerahnya. Kebutuhan masyarakat dan potensi yang berbeda-beda pada setiap daerah dapat menjadi penyebab adanya perbedaan tingkat deforestasi di Indonesia. Deforestasi sendiri dapat disebabkan oleh banyak faktor di antaranya adalah penebangan liar, kebakaran hutan, pembukaan lahan pertanian atau perkebunan, pertambangan, bencana alam, pembangunan pemukiman penduduk, dan faktor lain yang tingkat terjadinya dapat berbeda-beda pada tiap daerah. Dari banyaknya faktor yang dapat menjadi penyebab deforestasi tersebut maka akan dilakukan analisis regresi untuk mengetahui faktor yang memiliki peranan paling besar yang menjadi penyebab terjadinya deforestasi penutupan kawasan Hutan Lindung pada 34 Provinsi di Indonesia.

Faktor terjadinya deforestasi berdasarkan karakteristik daerah akan dipengaruhi oleh letak geografis antar daerah. Oleh karena itu diperlukan suatu metode pemodelan statistik 
yang memperhatikan letak geografis atau faktor lokasi pengamatan. Salah satu metode untuk menganalisisnya adalah dengan menggunakan model Geographically Weighted Regression (GWR) (Fotheringham et al., 2002). Model GWR merupakan pengembangan dari model regresi linier. Pada model regresi linier hanya dihasilkan estimator parameter yang berlaku secara global, sehingga sering disebut sebagai regresi global. Sedangkan dalam model GWR dihasilkan estimator parameter model yang bersifat lokal untuk setiap lokasi pengamatan (Purhadi \& Yasin, 2012).

Selain dipengaruhi oleh faktor perbedaan geografis, deforestasi juga mengalami perubahan pada setiap tahunnya. Hal ini yang menjadikan penulis ingin menganalisa ada atau tidaknya efek spasial sekaligus temporal dalam pemodelan proporsi deforestasi pada 34 Provinsi di Indonesia. Dengan memasukkan efek temporal ke dalam model Geographically Weighted Regression (GWR), maka akan didapat sebuah model GWR yang diperluas yaitu model Geographically and Temporally Weighted Regression (GTWR). Model Geographically and Temporally Weighted Regression (GTWR) telah dikembangkan untuk menangani ketidak stasioneran suatu data baik dari sisi spasial maupun temporal secara bersamaan. Tidak seperti model GWR, pada model GTWR kedua informasi dari temporal dan spasial digabungkan ke dalam matriks pembobot untuk melihat adanya heterogenitas spasial dan temporal (Acton, 2012).

\section{TINJAUAN PUSTAKA}

\subsection{Hutan}

Kumpulan pohon yang terdapat di beberapa tempat tidak dapat begitu saja disebut sebagai hutan. Begitu pula, hutan terdapat di beberapa tempat dan daerah, tetapi hutan tersebut diklasifikasikan dalam jenis hutan dan tipe hutan (Arief, 2001). Indonesia sendiri memiliki banyak jenis hutan, dikarenakan Indonesia merupakan negara tropis yang ditumbuhi berbagai jenis hutan. Hutan Indonesia, termasuk beberapa hutan yang secara hayati paling kaya di dunia, juga merupakan hutan paling banyak ditebang (Barber et al., 1999). Jeis hutan berdasarkan tujuannya terbagi menjadi Hutan Konservasi (HK), Hutan Lindung (HL), Hutan Produksi (HP), dan Areal Penggunaan Lain (APL) (Mutiara et al., 2018b).

\subsection{Deforestasi Hutan}

Deforestasi didefinisikan sebagai hilangnya atau terdegradasinya habitat hutan yang disebabkan oleh alam atau manusia. Lahan dan hutan terdegradasi didefinisikan sebagai lahan bekas hutan yang rusak parah karena terganggu secara intensif dan/atau terus menerus misalnya oleh kebakaran hutan atau penebangan liar lahan hutan yang rusak itu menjadi kurang produktif (Nawir, 2008). Deforestasi sendiri dapat disebabkan oleh banyak faktor di antaranya adalah penebangan liar, kebakaran hutan, pembukaan lahan pertanian atau perkebunan, pertambangan, bencana alam, pembangunan pemukiman penduduk, dan faktor lain.

\subsection{Regresi Linier}

Regresi merupakan suatu metode untuk mengukur besarnya pengaruh variabel bebas terhadap variabel terikat dan memprediksi variabel terikat dengan menggunakan variabel bebas (Gujarati, 2006).

\subsubsection{Uji Kecocokan Model Regresi Linier dan Uji Signifikansi Parameter}

Uji kecocokan model (uji F) digunakan untuk mengevaluasi pengaruh semua variabel independen terhadap variabel dependen, dengan daerah keputusan pada uji 
kecocokan model yaitu $H_{0}$ ditolak apabila $F_{\text {hitung }}>F_{(\alpha ; p, n-p-1)}$ atau jika nilai $P$-value $<\alpha$, dengan $\alpha$ merupakan taraf signifkansi. Sedangkan uji signifikansi parameter digunakan untuk mengetahui parameter yang signifikan pada model regresi linier dengan menggunakan uji parsial (uji t), dengan Daerah keputusan pada uji signifikansi parameter yaitu $H_{0}$ ditolak apabila $\left|t_{\text {hitung }}\right|>t_{\left(\frac{a}{2}, n-p-1\right)}$ atau jika nilai $P$-value $<\alpha$, dengan $\alpha$ merupakan taraf signifikansi.

\subsubsection{Uji Asumsi Residual Model Regresi Linier}

Dalam penggunaan regresi, terdapat beberapa asumsi dasar yang dapat menghasilkan estimator linier tidak bias yang terbaik dari model regresi yang diperoleh dari metode kuadrat terkecil biasa. Asumsi dasar itu dikenal dengan asumsi klasik yang terdiri dari homoskedastisitas, nonautokorelasi, nonmultikolinieritas, distribusi kesalahan (eror) adalah normal, nilai rata-rata kesalahan (eror) populasi pada model sama dengan nol dan variabel bebasnya mempunyai nilai yang konstan (Hasan, 2011).

\subsubsection{Uji Heteroskedastisitas Spasial}

Heterogenitas spasial terjadi akibat adanya perbedaan karakteristik satu wilayah dengan wilayah lainnya (efek wilayah yang random). Menguji heterogenitas spasial dalam model regresi sangat penting karena mengabaikan hal tersebut akan menyebabkan estimasi tidak efisien dan kesimpulan yang diperoleh kurang sahih. Pengujian heterogenitas spasial dilakukan dengan menggunakan statistik uji Breusch-Pagan Test (Purhadi \& Yasin, 2012).

\subsection{Geographically Weighted Regression}

Pada model GWR faktor geografis merupakan variabel prediktor yang dapat mempengaruhi variabel respon. Asumsi yang harus dipenuhi dalam model GWR adalah error berdistribusi normal dengan mean nol dan varians $\sigma^{2}$. Pada model Geographically Weighted Regression (GWR) hubungan antara variabel respon $\mathrm{Y}$ dan variabel bebas pada lokasi ke-i adalah: $Y_{i}=\beta_{0}\left(u_{i}, v_{i}\right)+\sum_{k=1}^{p} \beta_{k}\left(u_{i}, v_{i}\right) x_{i k}+\varepsilon_{i}, i=1,2, \cdots, n$

Metode yang digunakan untuk mengestimasi parameter model GWR yaitu Weighted Least Squares (WLS) dengan memberikan pembobot yang berbeda untuk setiap lokasi tempat data diamati. Pemberian bobot ini sesuai dengan Hukum I Tobler: 'Everything is related to everything else, but near thing are more related than distant thing (Segala sesuatu saling berhubungan satu dengan yang lainnya, tetapi sesuatu yang dekat lebih mempunyai pengaruh daripada sesuatu yang jauh)" (Miller, 2004).

Estimator parameter model GWR yaitu seperti pada Persamaan. 2

$$
\widehat{\boldsymbol{\beta}}\left(\mathrm{u}_{\mathrm{i}}, \mathrm{v}_{\mathrm{i}}\right)=\left[\mathbf{X}^{\mathrm{T}} \mathbf{W}\left(\mathrm{u}_{\mathrm{i}}, \mathrm{v}_{\mathrm{i}}\right) \mathbf{X}\right]^{-1} \mathbf{X}^{\mathrm{T}} \mathbf{W}\left(\mathrm{u}_{\mathrm{i}}, \mathrm{v}_{\mathrm{i}}\right) \mathbf{y}
$$

dengan $\widehat{\boldsymbol{\beta}}\left(\mathrm{u}_{\mathrm{i}}, \mathrm{v}_{\mathrm{i}}\right)$ merupakan estimator tak bias dan konsisten untuk $\boldsymbol{\beta}\left(\mathrm{u}_{\mathrm{i}}, \mathrm{v}_{\mathrm{i}}\right)$ (Leung et al., 2000), dengan matriks pembobot

$$
\mathbf{W}\left(\mathrm{u}_{\mathrm{i}}, \mathrm{v}_{\mathrm{i}}\right)=\left[\begin{array}{cccc}
\mathrm{w}_{\mathrm{i} 1} & 0 & \cdots & 0 \\
0 & \mathrm{w}_{\mathrm{i} 2} & \cdots & 0 \\
\vdots & \vdots & \ddots & \vdots \\
0 & 0 & \cdots & \mathrm{w}_{\text {in }}
\end{array}\right]
$$

$\mathbf{W}\left(\mathrm{u}_{\mathrm{i}}, \mathrm{v}_{\mathrm{i}}\right)$ adalah matriks pembobot spasial lokasi ke-i yang niai elemen-elemen diagonalnya ditentukan oleh kedekatan lokasi ke-i dengan lokasi lainnya. Semakin dekat lokasinya maka semakin besar nilai pembobot pada elemn yang bersesuaian. Salah satu fungsi pembobot spasial dalam GWR, diadopsi dari bentuk fungsi Kernel Gaussian (Fotheringham et al., 2002) 


$$
\mathrm{w}_{i j}=\sqrt{\exp \left(-1 / 2\left(d_{i j} / h\right)^{2}\right)}
$$

Dengan jarak Euclidian antar lokasi $\left(u_{i}, v_{i}\right): \mathrm{d}_{\mathrm{ij}}=\sqrt{\left(u_{i}-u_{j}\right)^{2}+\left(v_{i}-v_{j}\right)^{2}}$ dan $h$ adalah lingkaran radius bandwidth dari titik pusat lokasi.

\subsubsection{Pemilihan Bandwidth Optimum}

Salah satu metode untuk menentukan bandwidth optimum adalah cross validation. Metode Cross Validation atau sering disebut CV adalah metode penggunaan data untuk menunjukkan yang harus dilakukan jika pengulangan observasi tersedia (Hurdle, 1994). Secara matematis dapat dirumuskan seperti pada Persamaan. 4 (Fotheringham et al., 2002):

$$
C V=\sum_{i=1}^{n}\left(y_{i}-\widehat{y_{\neq l}}(h)\right)^{2}
$$

Dalam hal ini $\widehat{y_{\neq l}}(h)$ adalah penduga $y_{i}$ dengan pengamatan lokasi $\left(u_{i}, v_{i}\right)$ dihilangkan dari proses pendugaan. Untuk mendapatkan nilai bandwidth (h) yang optimal maka diperoleh dari h yang mengasilkan nilai CV yang minimum.

\subsection{Geographically and Temporally Weighted Regression}

Ketidakstasioneran suatu data baik dari sisi spasial maupun temporal secara bersamaan dapat ditangani dengan model Geographically and Temporally Weighted Regression (GTWR), yang merupakan pengembangan dari model Geographically Weighted Regression (GWR) (Wang, 2006). Model GTWR untuk $k$ variabel bebas dengan variabel terikat $y_{i}$ pada lokasi $\left\{\left(\mathrm{u}_{\mathrm{i}}, \mathrm{v}_{\mathrm{i}}, t_{i}\right)\right\}$ untuk setiap pengamatan dituliskan seperti pada

$$
\mathrm{Y}_{\mathrm{i}}=\beta_{0}\left(u_{i}, v_{i}, t_{i}\right)+\sum_{k=1}^{\mathrm{p}} \beta_{k}\left(u_{i}, v_{i}, t_{i}\right) \mathrm{x}_{i k}+\varepsilon_{i}
$$

Estimasi parameter pada model GTWR untuk setiap $p$ variabel dengan titik pengamatan $\left\{\left(u_{i}, v_{i}, t_{i}\right)\right\}$ dapat dilihat pada Persamaan. 6

$$
\widehat{\boldsymbol{\beta}}\left(u_{i}, v_{i}, t_{i}\right)=\left(\mathbf{X}^{\mathrm{T}} \mathbf{W}\left(u_{i}, v_{i}, t_{i}\right) \mathbf{X}\right)^{-1} \mathbf{X}^{\mathrm{T}} \mathbf{W}\left(u_{i}, v_{i}, t_{i}\right) \mathbf{Y}
$$

Dengan $\mathbf{W}\left(u_{i}, v_{i}, t_{i}\right)=\operatorname{diag}\left(\alpha_{\mathrm{i} 1}, \alpha_{\mathrm{i} 2}, \cdots, \alpha_{\mathrm{in}}\right)$ dan $\mathrm{n}$ adalah banyaknya pengamatan. Elemen diagonal $\alpha \mathrm{ij}(1 \leq \mathrm{j} \leq \mathrm{n})$ merupakan fungsi jarak spasial-temporal pada titik pengamatan $\left(u_{i}, v_{i}, t_{i}\right)$.

Misalkan data yang diamati terletak pada tiga dimensi dalam sistem koordinat spasial-temporal dan diketahui bahwa observasi tersebut memiliki kedekatan dengan titik i. Dalam hal ini digunakan sistem koordinat elipsoidal untuk mengukur kedekatan antara titik regresi dengan titik observasi yang mengelilinginya. Jarak spasial-temporal diilustrasikan pada gambar berikut

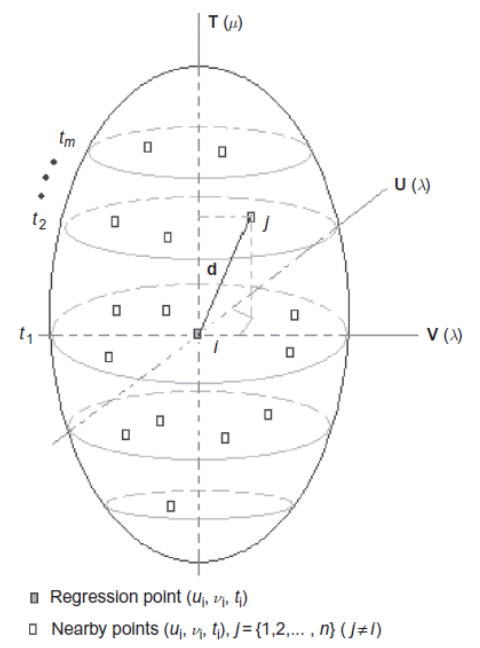

Gambar 1. Ilustrasi Jarak Spasial-Temporal (Huang, 2010) 
Fungsi jarak spasial-temporal terdiri dari gabungan fungsi jarak spasial dan fungsi jarak temporal. Dengan fungsi jarak spasial dS dan fungsi jarak temporal dT maka diperoleh persamaan seperti pada Persamaan. 7 berikut

$$
\left(d_{i j}^{S T}\right)^{2}=\lambda\left(d_{i j}^{S}\right)^{2}+\mu\left(d_{i j}^{T}\right)^{2}
$$

dengan nilai $\lambda$ dan $\mu$ menyatakan faktor skala penyeimbang efek yang berbeda untuk mengukur jarak spasial dan temporal. Sehingga jarak euclidean menjadi (Huang et al., 2010):

$$
\left(d_{i j}^{S T}\right)^{2}=\lambda\left\{\left(u_{i}-u_{j}\right)^{2}+\left(v_{i}-v_{j}\right)^{2}\right\}+\mu\left(t_{i}-t_{j}\right)^{2}
$$

Berdasarkan persamaan tersebut diperoleh

$$
\begin{aligned}
& \alpha_{i j}=\exp \left\{-\left(\frac{\lambda\left[\left(u_{i}-u_{j}\right)^{2}+\left(v_{i}-v_{j}\right)^{2}\right]+\mu\left(t_{i}-t_{j}\right)^{2}}{h_{S T}^{2}}\right)\right\} \\
& =\exp \left\{-\left(\frac{\left[\left(u_{i}-u_{j}\right)^{2}+\left(v_{i}-v_{j}\right)^{2}\right]}{h_{S}^{2}}\right)+\frac{\left(t_{i}-t_{j}\right)^{2}}{h_{T}^{2}}\right\}, \text { dengan } h_{S}^{2}=\frac{h_{S T}^{2}}{\lambda} \text { dan } h_{T}^{2}=\frac{h_{S T}^{2}}{\mu} \\
& =\exp \left\{-\left(\frac{\left(d_{i j}^{S}\right)^{2}}{h_{S}^{2}}+\frac{\left(d_{i j}^{T}\right)^{2}}{h_{T}^{2}}\right)\right\}, \text { dengan }\left(d_{i j}^{S}\right)^{2}=\left(u_{i}-u_{j}\right)^{2}+\left(v_{i}-v_{j}\right)^{2} \\
& =\exp \left\{-\frac{\left(d_{i j}^{S}\right)^{2}}{h_{S}^{2}}\right\} \times \exp \left\{-\frac{\left(d_{i j}^{T}\right)^{2}}{h_{T}^{2}}\right\}, \text { dan }\left(d_{i j}^{T}\right)^{2}=\left(t_{i}-t_{j}\right)^{2} \\
& =\alpha_{i j}^{S} \times \alpha_{i j}^{T}, \text { dengan } \alpha_{i j}^{S}=\exp \left\{-\frac{\left(d_{i j}^{S}\right)^{2}}{h_{S}^{2}}\right\} \text { dan } \alpha_{i j}^{T}=\exp \left\{-\frac{\left(d_{i j}^{T}\right)^{2}}{h_{T}^{2}}\right\}
\end{aligned}
$$

dengan $\mathrm{h}_{\mathrm{ST}}^{2}$ merupakan parameter dari bandwidth spasial-temporal

Misalkan $\tau$ merupakan parameter rasio dari $\frac{\mu}{\lambda}$ dengan $\lambda \neq 0$ maka diperoleh seperti pada persamaan berikut

$$
\frac{\left(d_{i j}^{T}\right)^{2}}{\lambda}=\left(u_{i}-u_{j}\right)^{2}+\left(v_{i}-v_{j}\right)^{2}+\tau\left(t_{i}-t_{j}\right)^{2}
$$

Parameter $\tau$ berfungsi untuk memperbesar atau memperkecil efek jarak temporal terhadap jarak spasial. Parameter ini didapatkan dari kriteria $\mathrm{CV}$ minimum melalui inisialisasi nilai $\tau$ awal. Selanjutnya estimasi parameter $\mu$ dan $\lambda$ bisa diperoleh berdasarkan hasil estimasi $\tau$ yang menghasilakan CV minimum (Huang et al., 2010).

\subsubsection{Pengujian Hipotesis Model GTWR}

Pengujian hipotesis pada model GTWR terdiri dari pengujian kesesuaian model GTWR dan pengujian parameter model. Pengujian kesesuaian model GTWR (goodness of fit) yang dilakukan dengan hipotesis sebagai berikut:

$\mathrm{H}_{0}: \beta_{k}\left(u_{i}, v_{i}, t_{i}\right)=\beta_{k}$ untuk setiap $k=0,1,2, \ldots, p$ dan $i=1,2, \ldots, n$

(tidak ada perbedaan yang signifikan antara model regresi global dan GTWR)

$\mathrm{H}_{1}$ : Paling sedikit ada satu $k$ sehingga $\beta_{k}\left(u_{i}, v_{i}, t_{i}\right) \neq \beta_{k}, k=0,1,2, \ldots, p$

(ada perbedaan yang signifikan antara model regresi global dan GTWR).

Penentuan statistik uji berdasarkan pada Residual Sum Square (RSS) yang diperoleh masing-masing dibawah $\mathrm{H}_{0}$ dan $\mathrm{H}_{1}$ sebagai berikut (Leung et al., 2000)

$$
\mathrm{F}_{1}=\frac{\operatorname{RSS}\left(\mathrm{H}_{1}\right) /\left(\frac{\delta_{1}^{2}}{\delta_{2}}\right)}{\operatorname{RSS}\left(\mathrm{H}_{0}\right) /(n-\mathrm{p}-1)}
$$

Dibawah $\mathrm{H}_{0}, \mathrm{~F}_{1}$ akan mengikuti distribusi $\mathrm{F}$ dengan derajat bebas $d f_{1}=\left(\frac{\delta_{1}^{2}}{\delta_{2}}\right)$ dan $d f_{2}=(n-\mathrm{p}-1)$. Jika diambil taraf signifikansi $\alpha$ maka $\mathrm{H}_{0}$ ditolak jika $\mathrm{F}_{1}<\mathrm{F}_{1-\alpha, \mathrm{df}_{1}, \mathrm{df}_{2}}$ 
Jika disimpulkan bahwa model GTWR berbeda nyata dengan model regresi global, maka langkah selanjutnya adalah melakukan uji parsial untuk mengetahui jika ada perbedaan pengaruh yang signifikan dari variabel prediktor $\mathrm{x}_{\mathrm{k}}$ antara satu lokasi dengan lokasi lainnya (Mei et al., 2004).

Pengujian ini dapat dilakukan dengan hipotesis :

$\mathrm{H}_{0}: \beta_{\mathrm{k}}\left(u_{1}, v_{1}, t_{1}\right)=\beta_{\mathrm{k}}\left(u_{2}, v_{2}, t_{2}\right)=\cdots=\beta_{\mathrm{k}}\left(u_{n}, v_{n}, t_{n}\right)$ untuk suatu $k=0,1,2, \cdots, p$

(tidak ada perbedaan pengaruh yang signifikan dari variabel prediktor $x_{\mathrm{k}}$ antar lokasi maupun waktu)

$\mathrm{H}_{1}$ : Minimal ada satu $k$ sehingga $\beta_{k}\left(u_{i}, v_{i}, t_{i}\right)$ untuk $\mathrm{i}=1,2, \ldots, \mathrm{n}$ yang berbeda.

(ada perbedaan pengaruh yang signifikan dari variabel prediktor $x_{\mathrm{k}}$ antar lokasi maupun waktu)

Dengan statistik uji pada persamaan

dengan:

$$
\mathrm{F}_{3}=\frac{\mathrm{V}_{\mathrm{k}}^{2} / \operatorname{tr}\left(\frac{1}{n} \boldsymbol{\beta}_{k}^{\mathrm{T}}\left[\mathbf{I}-\frac{1}{\mathrm{n}}\right] \boldsymbol{\beta}_{\boldsymbol{k}}\right)}{\operatorname{RSS}\left(\mathrm{H}_{1}\right) / \delta_{1}}
$$

$$
\boldsymbol{\beta}_{\boldsymbol{k}}=\left[\begin{array}{c}
\mathbf{e}_{\mathrm{k}}^{\mathrm{T}}\left[\mathbf{X}^{\mathrm{T}} \mathbf{W}\left(\mathrm{u}_{1}, \mathrm{v}_{1}, \mathrm{t}_{1}\right) \mathbf{X}\right]^{-\mathbf{1}} \mathbf{X}^{\mathbf{T}} \mathbf{W}\left(\mathrm{u}_{1}, \mathrm{v}_{1}, \mathrm{t}_{1}\right) \\
\mathbf{e}_{\mathbf{k}}^{\mathbf{T}}\left[\mathbf{X}^{\mathrm{T}} \mathbf{W}\left(\mathrm{u}_{2}, \mathrm{v}_{2}, \mathrm{t}_{2}\right) \mathbf{X}\right]^{-\mathbf{1}} \mathbf{X}^{\mathbf{T}} \mathbf{W}\left(\mathrm{u}_{2}, \mathrm{v}_{2}, \mathrm{t}_{2}\right) \\
\vdots \\
\mathbf{e}_{\mathbf{k}}^{\mathbf{T}}\left[\mathbf{X}^{\mathbf{T}} \mathbf{W}\left(\mathrm{u}_{\mathrm{n}}, \mathrm{v}_{\mathrm{n}}, \mathrm{t}_{\mathrm{n}}\right) \mathbf{X}\right]^{-\mathbf{1}} \mathbf{X}^{\mathbf{T}} \mathbf{W}\left(\mathrm{u}_{\mathrm{n}}, \mathrm{v}_{\mathrm{n}}, \mathrm{t}_{\mathrm{n}}\right)
\end{array}\right]
$$

$\mathbf{e}_{\mathbf{k}}$ adalah vektor kolom berukuran $(p+1)$ yang bernilai satu untuk elemen ke-k dan nol untuk lainnya.

Dibawah $\mathrm{H}_{0}$, statistik uji $\mathrm{F}_{3}$ akan berdistribusi $\mathrm{F}$ dengan derajat bebas

$\mathrm{df}_{1}=\left(\frac{\gamma_{1}^{2}}{\gamma_{2}}\right)$ dan $\mathrm{df}_{2}=\left(\frac{\delta_{1}^{2}}{\delta_{2}}\right)$ dengan $\gamma_{\mathrm{i}}=\operatorname{tr}\left(\frac{1}{\mathrm{n}} \boldsymbol{\beta}_{\mathrm{k}}^{\mathrm{T}}\left[\mathbf{I}-\frac{1}{\mathrm{n}} \mathbf{J}\right] \boldsymbol{\beta}_{\mathrm{k}}\right)^{\mathrm{i}}, \mathrm{i}=1,2$. Maka $\mathrm{H}_{0}$ ditolak jika $\mathrm{F}_{3}<\mathrm{F}_{\alpha, \mathrm{df}_{1}, \mathrm{df}_{2}}$ (Leung et al., 2000).

\subsubsection{Pemilihan Model Terbaik}

Menurut Gujarati (2006) ada beberapa metode yang digunakan untuk menentukan model terbaik, diantaranya :

\section{A. Koefisien Determinasi $\left(\mathbf{R}^{2}\right)$}

Nilai koefisien determinasi menunjukkan proporsi atau persentase variasi total dalam variabel respon yang dijelaskan oleh variabel prediktor. Koefisien determinasi didefinisikan sebagai berikut:

$$
\mathrm{R}^{2}=\frac{\mathrm{JK}}{\mathrm{JK}}=\frac{\sum_{\mathrm{i}=1}^{\mathrm{n}}\left(\widehat{\mathrm{Y}}_{\mathrm{i}}-\widehat{\mathrm{Y}}\right)^{2}}{\sum_{\mathrm{i}=1}^{\mathrm{n}}\left(\mathrm{Y}_{\mathrm{i}}-\widehat{\mathrm{Y}}\right)^{2}}
$$

dengan JKR merupakan jumlah kuadrat regresi dan JKT merupakan jumlah kuadrat total.

B. Mean Square Eror (MSE)

Mean Square Eror (MSE) adalah metode yang berperan dalam penentuan model terbaik dengan cara menguadratkan masing-masing kesalahan atau eror, selanjutnya dijumlahkan dan dibagi dengan jumlah observasi.

Berikut rumus untuk menghitung MSE :

$$
\operatorname{MSE}=\frac{1}{\mathrm{n}} \sum_{\mathrm{i}=1}^{\mathrm{n}}\left(\mathrm{Y}_{\mathrm{i}}-\widehat{\mathrm{Y}}_{\mathrm{i}}\right)^{2}
$$

\section{Akaike Information Criterion (AIC)}

Akaike Information Criterion (AIC) adalah salah satu kriteria untuk pemilihan model terbaik berdasarkan nilai yang terkecil (Fotheringham et al., 2002). Rumus perhitungan nilai AIC adalah sebagai berikut:

$$
A I C=2 n \ln (\hat{\sigma})+n \ln (2 \pi)+n+\operatorname{tr}(G)
$$


dengan:

$\hat{\sigma}$ : nilai estimator standar deviasi dari residual, yaitu $\hat{\sigma}^{2}=\frac{R S S}{n}$

$\mathrm{G}$ : matriks proyeksi dimana $\widehat{Y}=\boldsymbol{G} \boldsymbol{Y}$

Pemilihan model terbaik ditentukan dengan nilai $\mathrm{R}^{2}$ yang paling besar dan nilai MSE dan AIC terkecil

\section{METODE PENELITIAN}

\subsection{Sumber Data}

Dalam penelitian ini data yang digunakan adalah data sekunder mengenai faktorfaktor yang diduga mempengaruhi terjadinya perubahan deforestasi lahan pada kawasan Hutan Lindung (HL) di Indonesia yang diperoleh dari Kementerian Lingkungan Hidup dan Kehutanan (KLHK) melalui web site http://webgis.dephut.go.id/, Kebakaran Hutan dan Lahan melalui web site http://sipongi.menlhk.go.id, dan Badan Pusat Statistik Republik Indonesia melalui web site http://www.bps.go.id/.

Dalam penelitian ini, terdapat 34 provinsi di Indonesia yang dijadikan lokasi pengamatan. Data yang digunakan merupakan data pada tahun 2013 sampai dengan 2016.

\subsection{Variabel Penelitian}

Penelitian ini melibatkan beberapa variabel yang terdiri dari variabel dependen (Y) yang merupakan tingkat deforestasi pada kawasan hutan lindung pada 34 provinsi di Indonesia dari tahun 2013 sampai tahun 2016 dan variabel independen (X) yang terdiri dari:

a. Angka Tingkat Kebakaran Hutan $\left(\mathrm{X}_{1}\right)$

b. Luas Wilayah Perkebukan $\left(\mathrm{X}_{2}\right)$

c. Produksi Perkebunan Kelapa Sawit $\left(\mathrm{X}_{3}\right)$

d. Luas Wilayah Pemukiman Warga Pada Kawasan Hutan Lindung $\left(\mathrm{X}_{4}\right)$

e. Luas Wilayah Non-Hutan Pada Kawasan Hutan Lindung (X5)

f. Luas Wilayah Pertanian Lahan Kering Pada Kawasan Hutan Lindung ( $\left.\mathrm{X}_{6}\right)$

\subsection{Langkah Metode Analisa GTWR} adalah:

Langkah-langkah yang dilakukan untuk menganalisis data dalam penelitian ini

1. Menentukan variabel bebas yang diperkirakan mempengaruhi luas penutupan lahan pada kawasan hutan produksi tetap di 34 Provinsi Indonesia.

2. Melakukan pemodelan regresi global yang meliputi:

a. Estimasi parameter.

b. Pengujian serentak parameter regresi.

c. Pengujian parsial parameter regresi.

d. Pengujian asumsi klasik dan uji heterogenitas spasial-temporal.

3. Melakukan pemodelan GWR untuk mendapatkan bandwidth spasial $\left(\mathrm{h}_{\mathrm{s}}\right)$.

4. Melakukan pemodelan regresi lokal dengan GTWR yang meliputi:

a. Menghitung jarak Euclidian pada koordinat $\left(u_{i}, v_{i}, t_{i}\right)$.

b. Mendapatkan estimasi parameter $\tau, \mu$ dan $\lambda$.

c. Menentukan bandwidth spasial-temporal (hsT).

d. Menghitung besarnya pembobotan dengan metode Kernel Gaussian.

e. Estimasi parameter model GTWR.

f. Pengujian hipotesis untuk menentukan variabel yang mempunyai efek spasialtemporal.

5. Melakukan perbandingan model regresi global dan GTWR melalui kriteria nilai MSE dan $\mathrm{R}^{2}$. 


\section{HASIL DAN PEMBAHASAN}

\subsection{Deskripsi Data}

\begin{tabular}{|c|c|c|c|c|}
\hline Variabel & Maksimal & Minimal & Rataan & Standar Deviasi \\
\hline Deforestasi Lahan $(\mathrm{Y})$ & 50156,500 & 0 & 2146,770 & 5305,774 \\
\hline Kebakaran Hutan $\left(\mathrm{X}_{1}\right)$ & 30984,980 & 0 & 1680,973 & 4621,440 \\
\hline Luas Tanaman Perkebunan $\left(\mathrm{X}_{2}\right)$ & 54,600 & 0 & 3,188 & 7,814 \\
\hline $\begin{array}{c}\text { Produksi Tanaman Perkebunan Kelapa } \\
\text { Sawit }\left(\mathrm{X}_{3}\right)\end{array}$ & 8506,600 & 0 & 916,202 & 1658,490 \\
\hline Luas Wilayah Pemukiman Warga $\left(\mathrm{X}_{4}\right)$ & 3,500 & 0 & 0,489 & 0,749 \\
\hline Luas Kawasan Non Hutan $\left(\mathrm{X}_{5}\right)$ & 826 & 0 & 171,674 & 184,729 \\
\hline Jumlah Pertanian Lahan Kering $\left(\mathrm{X}_{6}\right)$ & 337,100 & 0 & 14,687 & 44,426 \\
\hline
\end{tabular}

4.2. Model Regresi Linier Berganda (Regresi Global) Tingkat Deforestasi Pada Kawasan Hutan Lindung (Model Regresi I)

Setelah dilakukan standarisasi pada data maka didapat model awal pada persamaan $\hat{Y}=0,009 X_{1}+0,063 X_{2}+0,282 X_{3}+0,054 X_{4}+0,257 X_{5}-0,259 X_{6}$

\subsubsection{Uji Kecocokan Model Regresi Linier dan Uji Signifikansi Parameter}

Pada uji kecocokan model regresi diperoleh bahwa nilai statistik uji F sebesar 4,076 dan nilai sig sebesar 0,000. Dengan keputusan menolak $\mathrm{H}_{0}$ karena $F_{\text {hitung }}(4,076)>$ $F_{(0.05 ; 6 ; 125)}(2,172)$ atau menolak $\mathrm{H}_{0}$ dikarenakan nilai $P$-Value $(0,000)<\alpha(0,05)$ maka dapat disimpulkan bahwa variabel independen secara serentak mempengaruhi variabel dependen. Pada uji signifikansi parameter diperoleh hasil dengan menggunakan metode pemilihan variabel dan menghasilkan 3 variabel dengan tingkat signifikansi kurang dari 0,05 dan $\left|t_{\text {hitung }}\right|$ lebih besar dari 1,979 yaitu variabel produksi tanaman perkebunan kelapa sawit, luas kawasan non hutan pada kawasan hutan lindung dan jumlah area pertanian lahan kering maka merupakan parameter yang signifikan terhadap faktor-faktor yang menyebabkan terjadinya deforestasi pada hutan lindung.

\subsubsection{Uji Asumsi Residual}

\section{A. Homogenitas Variansi Residual}

Uji Glejser menunjukkan nilai sig $=0,000<\alpha=0,05$ dan nilai $F_{\text {hitung }}(6,175)$ lebih besar dari $F_{(0,05 ; 6 ; 125)}(2,1719)$, maka $\mathrm{H}_{0}$ diterima sehingga variabel bebas tidak signifikan mempengaruhi nilai absolut residual. Jadi dapat disimpulkan bahwa asumsi homoskedastisitas tidak terpenuhi.

\section{B. Normalitas}

$\mathrm{H}_{0}$ ditolak karena $P$-Value $(0,000)<\alpha(0,05)$ sehingga residual tidak mengikuti distribusi normal

\section{Non-autokorelasi}

Nilai Durbin-Watson (d) sebesar 2,040. Karena nilai Durbin-Watson du $(1,8116)<$ $(2,040)<4-\mathrm{d}_{\mathrm{U}}(2,1884)$ maka $\mathrm{H}_{0}$ diterima sehingga tidak terjadi autokorelasi atau residual independen.

D. Non-multikolinieritas

\begin{tabular}{|c|c|c|}
\hline Variabel & VIF & Kesimpulan \\
\hline $\mathrm{X}_{1}$ & 1,170 & Tidak Terdapat Multikolinieritas \\
\hline $\mathrm{X}_{2}$ & 1,180 & Tidak Terdapat Multikolinieritas \\
\hline $\mathrm{X}_{3}$ & 1,587 & Tidak Terdapat Multikolinieritas \\
\hline $\mathrm{X}_{4}$ & 1,168 & Tidak Terdapat Multikolinieritas \\
\hline
\end{tabular}




\begin{tabular}{|c|c|c|}
\hline Variabel & VIF & Kesimpulan \\
\hline $\mathrm{X}_{5}$ & 1,363 & Tidak Terdapat Multikolinieritas \\
\hline $\mathrm{X}_{6}$ & 1,477 & Tidak Terdapat Multikolinieritas \\
\hline
\end{tabular}

Dapat disimpulkan bahwa di dalam model regresi yang terbentuk tidak terjadi multikolinieritas di antara variabel independen, sehingga asumsi non-multikolinieritas terpenuhi.

\subsection{3. $\mathbf{R}^{2}$, MSE dan AIC}

Model regresi mampu menjelaskan bahwa sebesar $16,40 \%$ persentase tingkat deforestasi pada kawasan hutan lindung dipengaruhi oleh variabel independen dan sisanya yaitu 83,60\% dipengaruhi oleh variabel lain di luar model. Kemudian nilai MSE dan AIC yang didapat dari model regresi sebesar 0,877 dan 365,0125 .

\subsection{Model Regresi II}

Pada proses uji t parameter keseluruhan telah didapat hasil parameter-parameter yang signifikan terhadap faktor-faktor yang menyebabkan terjadinya deforestasi pada kawasan hutan lindung di Indonesia. Parameter yang tidak signifikan akan dikeluarkan dari model.

Setelah dilakukan standarisasi pada data maka didapat model awal pada persamaan $\hat{Y}=0,308 X_{3}+0,276 X_{5}-0,262 X_{6}$

\subsubsection{Uji Kecocokan Model Regresi Linier dan Uji Signifikansi Parameter}

Pada uji kecocokan model regresi diperoleh nilai statistik uji $\mathrm{F}$ sebesar 8,084 dan nilai signifikansi sebesar 0,000 . Dengan keputusan menolak $\mathrm{H}_{0}$ karena $F_{\text {hitung }}(8,021)>$ $F_{(0,05 ; 3 ; 129)}(2,675)$ atau menolak $\mathrm{H}_{0}$ dikarenakan nilai $P$-Value $(0,000)<\alpha(0,05)$ maka dapat disimpulkan bahwa variabel independen secara serentak mempengaruhi variabel dependen. Pada uji signifikansi parameter diperoleh 3 variabel dengan tingkat signifikansi kurang dari 0,05 dan $\left|t_{\text {hitung }}\right|$ lebih besar dari 1,979 yaitu variabel produksi tanaman perkebunan kelapa sawit, luas kawasan non hutan pada kawasan hutan lindung dan jumlah area pertanian lahan kering maka merupakan parameter yang signifikan terhadap faktorfaktor yang menyebabkan terjadinya deforestasi pada hutan lindung.

\subsubsection{Uji Asumsi Residual}

\section{A. Heterogenitas Spasial-Temporal}

Dengan P-Value $(0,000)$ yaitu lebih kecil dari 0,05 dan nilai Breusch Pagan $(204,837)$ lebih besar dari nilai $\chi_{(3)}^{2}(6,251)$ menunjukkan bahwa ditemukan adanya kasus heterogenitas spasial.

\section{B. Normalitas}

$\mathrm{H}_{0}$ ditolak karena $P$-Value $(0,000)<\alpha(0,05)$ sehingga residual tidak mengikuti distribusi normal. Untuk mengikuti kaidah yang seharusnya residual dianjurkan untuk terdistribusi secara normal.

C. Non-autokorelasi

Nilai Durbin-Watson (d) sebesar 2,062. Karena nilai Durbin-Watson $\mathrm{d}_{\mathrm{U}}(1,7624)<$ $(2,062)<4-\mathrm{d}_{\mathrm{U}}(2,2376)$ maka $\mathrm{H}_{0}$ diterima sehingga tidak terjadi autokorelasi atau residual independen.

D. Non-multikolinieritas

\begin{tabular}{|c|c|c|}
\hline Variabel & VIF & Kesimpulan \\
\hline $\mathrm{X}_{2}$ & 1,324 & Tidak Terdapat Multikolinieritas \\
\hline $\mathrm{X}_{5}$ & 1,274 & Tidak Terdapat Multikolinieritas \\
\hline $\mathrm{X}_{6}$ & 1,448 & Tidak Terdapat Multikolinieritas \\
\hline
\end{tabular}


Dapat disimpulkan bahwa di dalam model regresi yang terbentuk tidak terjadi multikolinieritas di antara variabel independen, sehingga asumsi non-multikolinieritas terpenuhi.

\subsection{3. $R^{2}$, MSE dan AIC}

Model regresi mampu menjelaskan bahwa sebesar $15,80 \%$ persentase tingkat deforestasi pada kawasan hutan lindung dipengaruhi oleh variabel independen dan sisanya (yaitu 84,20\%) dipengaruhi oleh variabel lain di luar model. Kemudian nilai MSE dan AIC yang didapat dari model regresi sebesar 0,861 dan 361,3328.

\subsection{Pemodelan dengan GTWR}

\begin{tabular}{|c|c|c|c|c|c|}
\hline Variabel & Minimum & Maximum & Mean & Range & Std, Deviasi \\
\hline Constant & 0,0372 & 0,1040 & 0,0704 & 0,0667 & 0,0162 \\
\hline X3 & 0,1809 & 0,5240 & 0,3285 & 0,3432 & 0,1181 \\
\hline X5 & 0,1254 & 0,6219 & 0,4685 & 0,4966 & 0,1416 \\
\hline X6 & $-0,4483$ & $-0,2823$ & $-0,3708$ & 0,1660 & 0,0389 \\
\hline
\end{tabular}

Esimasi parameter $\beta_{0}$ pada lokasi pengamatan tingkat deforestasi di Indonesia berkisar antara 0,0372 hingga 0,1040. Sementara variabel prediktor produksi tanaman perkebunan kelapa sawit dan nilai jumlah non hutan kawasan hutan lindung bervariasi pada setiap lokasi dengan rata-rata positif, artinya semakin naik nilai produksi tanaman perkebunan kelapa sawit dan nilai jumlah non hutan kawasan hutan lindung maka semakin meningkat pula tingkat deforestasi pada kawasan hutan lindung di Indonesia.

\subsubsection{Pengujian Hipotesis Model GTWR}

\begin{tabular}{|c|c|c|c|c|c|}
\hline Sumber & Sum of Squares & Df & Mean Squares & F & P \\
\hline Improvement & 12,1063 & 5,6847 & 2,1296 & 5,706 & 0,0298 \\
\hline GTWR & 98,1635 & 125,2918 & 0,7835 & & \\
\hline Regresi & 110,2698 & 128,000 & & & \\
\hline
\end{tabular}

Dapat dilihat bahwa $P$-value $(0,0298)<0,05$ maka terdapat perbedaan yang signifikan antara model regresi global dan GTWR yang mengindikasikan bahwa adanya pengaruh spasial-temporal.

\subsubsection{Uji Faktor Spasial-Temporal pada Setiap Variabel}

Variabel produksi tanaman perkebunan kelapa sawit $\left(\mathrm{X}_{3}\right)$ dan jumlah non hutan kawasan hutan lindung $\left(\mathrm{X}_{5}\right)$ dengan nilai $\mathrm{F}_{3}$ berturut-turut adalah 11,4426 dan 11,1398 keduanya lebih besar dari $\mathrm{F}_{(0,05 ; 6 ; 125)}(2,1719)$. Serta P-value berturut-turut adalah 0,0004 dan 0,0003 keduanya lebih kecil dari 0,05 maka menolak $\mathrm{H}_{0}$, sehingga ada perbedaan pengaruh yang signifikan dari variabel produksi tanaman perkebunan kelapa sawit $\left(\mathrm{X}_{3}\right)$ dan jumlah non hutan kawasan hutan lindung $\left(\mathrm{X}_{5}\right)$ antar lokasi maupun waktu. Untuk variabel jumlah pertanian lahan kering $\left(\mathrm{X}_{6}\right)$ menunjukkan nilai $\mathrm{F}_{3}$ sebesar 2,0382 nilai tersebut lebih besar dari $\mathrm{F}_{(0,05 ; 6 ; 125)}(2,1719)$, sedangkan untuk nilai $P$-value pada variabel $\mathrm{X}_{6}$ yaitu 0,1482 lebih besar dari 0,05. Maka dengan begitu dapat diambil kesimpulan bahwa variabel jumlah pertanian lahan kering $\left(\mathrm{X}_{6}\right)$ menerima $\mathrm{H}_{0}$. Sehingga pada variabel jumlah pertanian lahan kering $\left(\mathrm{X}_{6}\right)$ tidak terdapat perbedaan pengaruh yang signifikan antar lokasi maupun waktu.

\subsection{3. $\mathbf{R}^{2}$, MSE dan AIC}

Nilai koefisian determinasi $\mathrm{R}^{2}$ yang dihasilkan dari model GTWR yang terbentuk sebesar 0,251 artinya model GTWR mampu menjelaskan bahwa sebesar 25,10\% persentase 
deforestasi pada kawasan hutan lindung dipengaruhi oleh variabel independen dan sisanya yaitu $74,90 \%$ dipengaruhi oleh variabel lain di luar model. Kemudian nilai MSE yang didapat dari model regresi sebesar 0,7835 dan juga nilai AIC yang didapat dari model regresi sebesar 349,6917.

\subsubsection{Perbandingan Model Regresi Global dan Model GTWR}

\begin{tabular}{|c|c|c|c|}
\hline Metode & $\mathbf{R}^{\mathbf{2}}$ & MSE & AIC \\
\hline Regresi Global & 0,158 & 0,861 & 361,3328 \\
\hline GWR & 0,248 & 0,7845 & 349,7915 \\
\hline GTWR & 0,251 & 0,7835 & 349,6917 \\
\hline
\end{tabular}

Hasil tersebut menunjukkan bahwa regresi global hanya memberikan nilai $\mathrm{R}^{2}$ sebesar 0,158, MSE sebesar 0,861 dan AIC sebesar 361,3328 sedangkan model GTWR mampu memaksimalkan nilai $\mathrm{R}^{2}$ sebesar 0,251 dengan nilai MSE dan AIC lebih kecil daripada regresi global yaitu 0,7835 dan 349,6917. Dapat dilihat pula bahwa model GTWR juga memberikan hasil yang lebih baik jika dibandingkan dengan model GWR yang memiliki nilai $\mathrm{R}^{2}$ sebesar 0,248 dengan nilai MSE dan AIC lebih besar daripada GTWR yaitu 0,7845 dan 349,7915 .

\section{KESIMPULAN}

Dari hasil analisis dan pembahasan mengenai pemodelan tingkat deforestasi pada kawasan hutan lindung di Indonesia dengan menggunakan metode regresi global dan GTWR, maka dapat diperoleh kesimpulan, di antaranya adalah:

1. Faktor-faktor yang signifikan mempengaruhi tingkat deforestasi pada kawasan hutan lindung di Indonesia berdasarkan model regresi global adalah produksi tanaman perkebunan kelapa sawit, jumlah non hutan kawasan hutan lindung dan jumlah pertanian lahan kering.

2. Pada pemodelan GTWR ditemui bahwa adanya perbedaan pengaruh yang signifikan antara lokasi maupun waktu pada variabel produksi tanaman perkebunan kelapa sawit, jumlah non hutan kawasan hutan lindung dan jumlah pertanian lahan kering. Maka pada ketiga variabel tersebut ditemui adanya efek spasial-temporal.

3. Dari perbandingan yang telah dilakukan maka diperoleh hasil bahwa pemodelan tingkat deforestasi pada kawasan hutan lindung di Indonesia menggunakan metode GTWR lebih baik daripada menggunakan regresi global. Hal ini dikarenakan regresi global hanya memberikan nilai $\mathrm{R}^{2}$ sebesar 0,158 , MSE sebesar 0,861 dan AIC sebesar 361,3328 sedangkan model GTWR mampu memaksimalkan nilai $\mathrm{R}^{2}$ sebesar 0,251 dengan nilai MSE dan AIC lebih kecil daripada regresi global yaitu 0,7835 dan $349,6917$.

\section{DAFTAR PUSTAKA}

Acton, Q. A. (2012). Advances in Information Technology Research and Application/ 2011 Edition. Atlanta, Georgia: Scholarly Editions.

Arief, M. P, I. (2001). Hutan dan Kehutanan. Yogyakarta: Kanisius.

Barber, C. V., Johnson, N. C., \& Hafild, E. (1999). Breaking the Logjam: Obstacles to Forest Policy Reform in Indonesia and The United States. Jakarta: Yayasan Obor Indonesia.

Fotheringham, A. S., Brunsdon, C., \& Charlton, M. (2002). Geographically Weighted Regression: The Analysis Of Spatially Varying Relationships. West Sussex, England: John Wiley \& Sons Ltd.

Gujarati, D. (2006). Ekonometrika Dasar. Erlangga. 
Hasan, M. I. (2001). Pokok-Pokok Materi Statistik 2: Statistik Inferensi. Jakarta: Bumi Aksara.

Huang, B., Wu, B., \& Barry, M. (2010). Geographically and Temporally Weighted Regression for Modeling Spatio-Temporal Variation in Houses Prices. International Journal of Geographical Information Science, 383-401.

Hurdle, W. (1994). Applied Nonparametric Regression. Berlin.

Leung, Y., Mei, C. L., \& Zhang, W. X. (2000). Statistical Test for Spatial Nonstationarity Based On The Geographically Weighted Regression Model. Environment and Planning A, 32, 9-32.

Mei, C., He, S. Y., \& Fang, K. T. (2004). A Note on the Mixed Geographically Weighted Regression Model. Journal of Regional Science, 143-157.

Miller, H. J. (2004). Tobler's First Law and Spatial Analysis. Annals of the Association of America Geographers, 284-289. 